\title{
Examining the Efficacy of Co-operative Learning Strategy on Undergraduate Students' Achievement in Mathematics
}

\author{
Adeneye O. A. Awofala ${ }^{1}$, Abisola O. Lawani ${ }^{2}$ \\ ${ }^{1}$ Department of Science and Technology Education, Faculty of Education, University of Lagos, \\ Akoka, Lagos State, Nigeria \\ ${ }^{2}$ Department of Mathematics, College of Science and Information Technology, Tai Solarin \\ University of Education, Ijagun, Ogun State, Nigeria \\ Corresponding email: aawofala@unilag.edu.ng
}

\begin{abstract}
Evidence suggests strong support for innovative teaching approaches in mathematics intervention in universities all over the world and robust backing has been accorded to co-operative learning pedagogy, which provides strong professional development to teachers on ways of promoting students' social skills and aiding them to learn in a constructivist way. There is no doubt that cooperative learning is one of the most extensively documented pedagogical methods in mathematics, but little is known about its efficacy in the Nigerian university education setting. This study investigates the effectiveness of cooperative learning strategy on the achievement in mathematics of 220 university students in Nigeria, within the blueprint of the quasi-experimental research of the Solomon four non-equivalent control group design. It also examines the influence of gender on students' achievement in mathematics. Gender was included in this study because of the inconsistencies in the research findings regarding its influence on achievement in mathematics and the importance placed on it in mathematics education research. Achievement in mathematics was measured by the differentiation achievement test with KR-20 of 0.86 and the data collected for the study were analysed by adopting the independent samples t-test and a $4 \times 2$ analysis of variance (ANOVA). The $4 \times 2$ ANOVA was used to contrast the treatment at four levels (cooperative learning with a pre-test and post-test; cooperative learning with a post-test only; a conventional teaching approach with a pre-test and post-test; and a conventional teaching approach with a post-test only) and gender at levels (male and female). The results show a significant main effect of co-operative learning strategy on students' achievement in mathematics, whereas no significant main influence of gender was found on such achievement. In addition, there was no significant interaction effect of treatment or gender on students' achievement in mathematics. Based on the positive social effect of cooperative learning strategy in raising university students' achievement in mathematics in this study, it is paramount to adjust cooperative learning principles to enhance the needs of universities in Nigeria. Integrating technology to enhance
\end{abstract}


the enactment of major pedagogical elements of cooperative learning and to differentiate teaching and learning to improve the numerous needs of students may provide scope for optimising the mathematics results of Nigerian students.

Keywords: co-operative learning; mathematics achievement; gender; undergraduate students

DOI: https://dx.doi.org/10.20961/ijpte.v4i1.33402 


\section{INTRODUCTION}

This study assesses the efficacy of cooperative learning in tertiary mathematics, in terms of students' achievement during lessons. At the university level, mathematics educators are always motivated to advance student performance and achievement in the subject area. The concerns over learning difficulties in mathematics and the dearth of metacognitive consciousness of mathematical intelligence and creative problem-solving skills (Tarmizi \& Bayata, 2012) appear to continue, and despite variances amongst educators regarding the most effective learning practice, it suggests that there is a slightest consensus concerning the low level of success amongst students in mathematics (Ali, Hukamdad \& Khan, 2010). At higher levels, mathematics is regarded as a difficult and uninteresting subject by many students, with weaker students showing not only anxiety about it, but also displaying low mathematics self-efficacy and negative attitudes. Students who are deficient in mathematics proficiency are less successful and perform poorly in university tests and examinations. This low proficiency in mathematics reveals that students are not actively involved in constructing and developing knowledge, as they receive mathematics knowledge passively and are less motivated and less inspired to learn the subject successfully. The passivity in mathematics classes around the world has triggered much apprehension among educators because mathematics knowledge serves as a catalyst for improving a country's social and economic growth and development. The teaching method adopted in mathematics classes can be one of the factors that renders students inactive and less interactive with each other when undertaking mathematics tasks. For the last 35 years there has been a reform of the mathematics education programme as a response to discontent with traditional teaching methods (The Education Alliance, 2006). Particular reports endorsing the reformation of mathematics teaching (National Council of Teaching of Mathematics [NCTM], 1989) have brought about the need for alterations in educational practice.

The NCTM (2011) recommends a move away from conventional mathematics classrooms to reform-oriented ones that focus on effective pedagogical mediations allowing students to be actively engaged in cooperative settings. Employing several models and methods of constructing topics can promote excellent adaptations of the content to better support student's desires in maths (NCTM, 2011). Educators should be more concerned with promoting active learning activities that will ensure students' construction of knowledge in mathematics, and one effective way of achieving this is to acquaint students with cooperative learning (NCTM, 1989; Davidson, 1985). The present adoption of the lecture mode of delivery in universities shows that students are learning mathematics through traditional behaviouristic methods (Tarmizi \& Bayata, 2012), which often makes them unreceptive and reliant on their lecturers (Wood, Cobb \& Yackel, 1991). Contemporary mathematics teaching centres on a constructivist approach, which helps students to adopt prior knowledge in mathematics to face new challenges, with the hope of obtaining new information for effective and momentous elucidation and in-depth comprehension of the taught material (Amit $\&$ Fried, 2002). At the same time, it does not ignore the vital role of traditional 
instruction in mathematics, and admits that, in a competitive educational milieu, students are more often compensated for individual effort. This study aims to strengthen and expand the previously published literature on cooperative learning, with specific emphasis on mathematics at the university level. It is argued that it is possible to make once-disbelieving educators, who have criticised cooperative learning as a difficult strategy which creates group hate in higher mathematics, understand and consider the value and benefits inherent in cooperative learning for their students (Nardi \& Stewart, 2003). Cooperative learning has been found to promote educational attainment, improve social interaction, and improve emotional and psychological vigour (Johnson, Johnson \& Smith, 2013).

The educational attainment stimulated by cooperative learning can increase students' academic achievement or reduce educational failure; promote cognitive regulation and intelligent assimilation in the school community; aid learners decide their career and educational goals; increase the chances of virtues they may achieve intellectually; enhance educational pledges; promote tendencies for scholarship; and enhance analogy amid cognitive motivations and school curricula. In addition, the positive social interactions nurtured by cooperative learning practices can promote shared pressure to study and accomplish tasks; regulate to fresh interactions and turn out to be informally integrated into school culture; help promote group goals; diminish improbability about goals; promote obligations to colleagues; and enhance similarity amid going to school and rapport goals. Moreover, the improved emotional vigour endorsed through cooperative learning practices can improve students' educational self-worth and confidence; emotional regulation; elucidate individual goals; improve the capability to manage insecurity; encourage productive interactions with different school colleagues; establish alliances in order to attain goals; and provide the capability to adjust one's goals to present conditions.

Although cooperative learning has been extensively adopted in schools worldwide, with a rich, impressive and solid research base (Johnson, Johnson \& Smith, 2013; Celikten, Ipekcioglu, Ertepinar, \& Geban, 2012; Johnson, Johnson, \& Holubec, 1994), there is a dearth of research on how working in cooperative learning environments influences Nigerian university students' academic achievement in mathematics (Awofala, Fatade \& Ola-Oluwa, 2012). This study therefore examines the efficacy of cooperative learning in university-level mathematics, which is perhaps somewhat lacking in research output in Nigeria, by investigating enhanced student achievement after the implementation of the cooperative learning interface.

Cooperative learning is based on the theoretical frameworks of social interdependence, cognitive development, and behavioural learning. Evidence suggests that it takes a greater effort to accomplish, but leads to more positive relationships and greater emotional health than competitive or individualistic learning efforts (Johnson, Johnson, \& Holubec, 1994). Social interdependence theory perceives cooperation as a result of positive links between individuals in achieving a common goal. Kurt Koffka anticipated in the early 1900s that although groups are vibrant wholes, interdependence amongst members varies. 
Such interdependence developed from shared goals provides the indispensable kernel of a group (Lewin, 1948), thus creating the vibrant whole. The power of a group is such that the modification of any member or subgroup directly alters other members and subgroups.

Whenever two people work together, the likelihood of cooperation occurs. For this to develop in students, the following conditions must be satisfied. Based on social interdependence theory, these conditions are group processing, individual accountability, social skills, promotive interaction, and positive interdependence (Johnson \& Johnson, 1989, 2005). Within cognitive development theory, cooperation must go before cognitive growth. Such growth evolves from the configuration of various viewpoints as individuals work to reach common goals. Both Piaget and Vygotsky believed that cooperative learning with academically stronger peers and instructors produced cognitive development and intellectual growth (Johnson, Johnson \& Smith, 1998). The supposition of behavioural learning theory is that students will work hard and show perseverance on tasks that provide a reward contingent but that they will be reluctant to do so on tasks that provide no reward or punishment. Cooperative learning is one pedagogical strategy that gives rewards to individuals for participating in the group effort. It is a mode of learning in which students of different ability levels work together in small groups to develop both academic and social relationships, cross-examine issues, share ideas, elucidate differences, and construct new understanding to accomplish a common group goal. Such learning not only encourages students to be active contributors in the construction of their own knowledge (Webb, Troper, \& Fall, 1995), but also allows them to network and converse with peers in agreement. Therefore, cooperative learning could be seen to be promoting values such as trustworthiness, teamwork, shared esteem, accountability, patience, and eagerness to sacrifice an agreement.

Despite the thousands of studies conducted on cooperative learning world-wide in the last century, the new millennium has witnessed increased research on cooperative learning in mathematics at the primary and secondary school levels (Celikten, Ipekcioglu, Ertepinar, \& Geban, 2012). This avalanche of research on the use of cooperative learning strategies agrees that students at primary and secondary grade levels experience growth in their achievement in subject areas, increased understanding of given topics, and a rise in motivation, and that cooperative learning leads to productive and valuable results for student learning (Celikten et al., 2012; Kilpatrick, 1992; Ebrahim, 2012; Galton, Hargreaves, \& Pell, 2009; Law, 2011; Souvignier, \& Kronenberger, 2007; Tarim, 2009; Pierce, Cassady, Adams, Speirs Neumeister, Dixon, \& Cross, 2011).

The literature includes many studies conducted to examine the effectiveness of competitive, individualistic, and cooperative methodologies in improving productivity and achievement (Johnson \& Johnson, 1990; Johnson, Johnson \& Smith, 2013). In a meta-analysis of achievement in cooperative learning, the results showed that average student learning through cooperative methods performed at around two-thirds a standard deviation above the average student learning within a competitive effect size of 0.67) or individualistic (effect size of 
0.64) structured lesson (Johnson, Johnson \& Smith, 1991). These results showed the efficacy of cooperative learning in increasing the achievement levels of students compared to competitive or individualistic learning strategies. According to Curtis (2001), cooperative learning deals with tasks that are dividable into more or less autonomous subtasks, where cooperating teams work together to process discrete subtasks in an independent, self-governing way, which is different to collaborative learning, in which a joint solution to a problem is constructed concurrently, mutually and in connection with all members of the group.

Since learning mathematics at higher levels is often seen as a lonely, individualistic or competitive activity, with students exhibiting anxiety and showing avoidance behaviours, cooperative learning can overcome these problems and facilitate students' growth and attainment in the subject (D'Souza \& Wood, 2003). Mathematics provide the opportunity for innovative thinking, and exploring open-ended questions and intriguing problems, and cooperative learning can help to solve these problematic and challenging tasks that are outside the reach of individual capacities at the growing stage.

Cooperative learning can be a convenient and helpful strategy to help students develop academically and socially. Its academic benefits include higher achievements in reading comprehension (Mathes, Fuchs, \& Fuchs, 1997) and mathematics (Awofala, Fatade \& Ola-Oluwa, 2012) and enriched conceptual understanding and achievement in science (Lonning, 1993). The social benefits may include perseverance in tasks and the facilitation of interactions with group members (Burron, James, \& Ambrosio, 1993; Gillies \& Ashman, 1998; McManus \& Gettinger, 1996), greater self-confidence, more friends, more participation in classroom activities, and better attitudes toward learning in general (Lazarowitz, Baird, \& Bolden, 1996; Lazarowitz, Hertz-Lazarowitz, \& Baird, 1994). Such learning can sometimes be less successful because of the reduced comprehension of the vital components that mediate its efficacy. For example, weaker members of the team can sometimes leave team exercises for others to complete, whereas strong team members might neglect exercises by putting in less effort to avoid doing all the work. However, the co-operative learning that is commonly undertaken in schools comprises amorphous group work, with little individual responsibility and no common group goals (Stein, Grover, \& Henningsen, 1996; Hiebert \& Wearne, 1993). The failure of cooperative learning can be explained in terms of student characteristics. For instance, students who were accustomed to learning passively from teachers, taking notes, and preparing for tests and examinations individually would find it extremely difficult to engage in active investigation of a topic, acquire information by themselves or from their peers, or to learn in teams. In this case, students would experience difficulty in researching topics because in a competitive environment they did not have to conduct research, but rather record the material that teachers presented in the class. Therefore, this passive learning culture completely negates the cooperative learning principle of students being active and independent in their learning.

It is a fact that the amount of time spent on explaining concepts can be directly and positively related to the amount of time spent on learning, so the stronger 
members of a cooperative team can learn much by giving detailed elucidations of the taught material to the weaker students who are struggling to understand it (Kerr \& Bruun, 1983). Mathematics educators play a significant role in the effective implementation of cooperative learning in the classroom, as they act both as content analysts and classroom administrators (Johnson \& Johnson, 1990), who are able to identify the specific behavioural objectives of the lesson, make pedagogical decisions, and explain tasks showing the assignment goals (Smith, 1996) for the realisation of the learning outcome.

The three null hypotheses formulated and tested in this study at the $\alpha=.05$ level of significance are:

a. There is no significant main effect of treatment (cooperative learning strategy and conventional teaching approach) on university students' achievement in mathematics;

b. There is no significant main influence of gender on university students' achievement in mathematics; and

c. There is no significant interaction effect of treatment or gender on university students' achievement in mathematics.

Note that an interaction effect is the concurrent effect of two or more independent variables (in this case instructional strategy at two levels and gender at two levels) on at least one dependent variable (in this case achievement in mathematics), in which their joint effect is significantly greater (or significantly less) than the sum of their parts.

\section{MATERIALS AND METHODS}

This study adopted a quantitative research approach within the scheme of quasiexperimental design. The non-equivalent Solomon four control group design was implemented to test the null hypothesis. The design was carefully chosen because it was not possible to randomise students to groups comparatively because the unit of sampling, a class, had already been formed. Therefore, it was unprincipled to reorganise one randomly. In addition, undergraduate classes exist as intact groups with definite times for lectures, which may pose difficulties in reconstituting them for research purposes (Gall, Borg \& Gall, 1996). The research design is shown in Figure 1.

$\begin{array}{llcc}\text { Group } \mathrm{E}_{1} & \mathrm{O}_{1} & \mathrm{X} & \mathrm{O}_{2} \\ & -\mathrm{O}_{3} & - & \mathrm{O}_{4} \\ \text { Group } \mathrm{C}_{1} & \underline{\mathrm{O}}_{3} & \mathrm{X} & \mathrm{O}_{5} \\ \text { Group } \mathrm{E}_{2} & & --------\mathrm{O}_{6}\end{array}$

Figure 1. Solomon Four Non-Equivalent Control Group Research Design

In the follow-up, $\mathrm{O}_{1}$ and $\mathrm{O}_{3}$ were pre-test. The pre-test is the preliminary MAT given to participants before the commencement of treatment. $\mathrm{O}_{2}, \mathrm{O}_{4}, \mathrm{O}_{5}, \mathrm{O}_{6}$ were the post-test. The post-test is a rearranged MAT given to the participants after the 
completion of the treatment or instructional programme. $\mathrm{X}$ was the treatment by which students were taught using the cooperative learning strategy. The dotted line refers to the participation of whole groups, and the design involved an arbitrary allotment of intact classes to four different groups. Group $\mathrm{E}_{1}$ was the experimental group, which was given the pre-test, treatment $\mathrm{X}$ and the post-test. Group $\mathrm{C}_{1}$ was the control group, which was given the pre-test, followed by the control condition and then the post-test. Group $\mathrm{E}_{2}$ was given treatment $\mathrm{X}$ and the post-test, but not the pre-test, while group $\mathrm{C}_{2}$ was given the post-test only as it was the control group. Groups $\mathrm{C}_{1}$ and $\mathrm{C}_{2}$ were given the control condition of the lecture method, while Groups $\mathrm{E}_{1}$ and $\mathrm{E}_{2}$ were treated with the experimental condition of cooperative learning. This design prohibited all major threats to internal validity, apart from those associated with interactions of selection and maturation, selection and instrumentation, and history. No major event was detected in any of the sampled universities that would have justified interaction between selection and history. To control for interaction between selection and maturation, the universities were assigned arbitrarily to the control and treatment groups. To control for interaction between selection and instrumentation, the conditions under which the instrument was administered were kept as similar as possible in all the universities (Awofala, 2016a; Shihusa \& Keraro, 2009).

The target population for the study consisted of all BSc Education degree students taking mathematics in four public universities in the states of Lagos and Ogun in southwest Nigeria. This geo-political zone was chosen because it has the highest number of universities (public and private) and is regarded as the cradle of higher education in Nigeria. An intact class of first year mathematics education students (freshmen) was purposively selected from each university. Purposive sampling was used based on the following criteria: each intact class must comprise students studying BSc. Ed mathematics and must be a first year class, in which calculus is taught. Each intact class of the first-year mathematics education students from each university was randomly assigned by the simple random sampling technique to experimental groups I and II and control groups I and II. Overall, the sample consisted of 220 students (112 females and 108 males), whose mean age was 20 ( $\mathrm{SD}=2$ years 2 months). The selection of these students was considered appropriate, since older students in the university seem to benefit more from cooperative learning than younger students at secondary school. The reason for this is attributed to the fact that older students possess more developed schemata for processing information in a real-world context (Awofala, 2010) and taking on active roles in co-operative learning to gain social skills is never a problem for them. Table 1 shows the distribution of the students in the four groups. 
Table 1. Distribution of students in the experimental and control groups by gender

\begin{tabular}{lll}
\hline Treatment Group & Gender & $\mathrm{N}$ \\
\hline Experimental group I & Male & 28 \\
& Female & 27 \\
& Total & 55 \\
\hline Control group I & Male & 31 \\
& Female & 29 \\
& Total & 60 \\
\hline Experimental group II & Male & 24 \\
& Female & 26 \\
& Total & 50 \\
\hline Control group II & Male & 25 \\
& Female & 30 \\
& Total & 55 \\
\hline
\end{tabular}

One instrument, the Differentiation Achievement Test (DAT) was used for the data collection. The DAT, which was used to assess the achievement of students in differentiation, was developed by the researchers. The DAT used as the pretest and post-test consisted of 30 multiple choice items with options A to D and covered topics related to differentiation of algebraic functions, differentiation of trigonometric functions, differentiation of composite functions, chain rule, quotient rule, and derivatives of implicit and parametric functions, as contained in the first year handbook of undergraduate mathematics. The initial 40 items of the DAT were subjected to face and content validation by two mathematics lecturers at the University of Lagos, Akoka, Lagos, Nigeria. The validation involved checking the DAT items against the topic of the lesson plan, language editing, and suitability of the test for the target participants. Five items were removed based on the experts' recommendations and the face-validated DAT was verified for difficulty index and discrimination power. Items with a difficulty power of 0.40.6 , discrimination power of 0.2 and above, and distracter index of negative decimal were retained (Akinsola \& Awofala, 2009). In line with this, five items were omitted, leaving the final 30 items for the DAT, which was trial-tested with 80 first year undergraduate mathematics students in a university not taking part in the study. The reliability coefficient of the DAT was found to be 0.86 using Kuder-Richardson 20 formulae. Each item on the DAT was scored with up to 11/2 marks, meaning a total score of 45 marks was attainable. The DAT covered the last three levels of the Bloom taxonomy of cognitive domains, known as the higher-order cognitive domain (analysis-A, synthesis-S, and evaluation-E), as shown in the specification table (Table 2) below. 
Table 2. Differentiation Achievement Test (DAT) Item Specification

\begin{tabular}{lllll}
\hline Topic & Level of cognitive domain & \\
& $\mathrm{A}$ & $\mathrm{S}$ & $\mathrm{E}$ & Total \\
\hline Differentiation of algebraic functions & 2 & 2 & 2 & 6 \\
& & & & \\
\hline Differentiation of trigonometric functions & 2 & 2 & 2 & 6 \\
& & & & \\
\hline Differentiation of composite functions & 2 & 2 & 2 & 6 \\
& & & & \\
\hline Chain and quotient rules & 2 & 2 & 2 & 6 \\
\hline Derivatives of implicit \& parametric functions & 2 & 2 & 2 & 6 \\
\hline$\quad$ Total & & & & \\
\hline
\end{tabular}

The study was conducted over seven weeks and involved four classes with a mathematics lecturer in each one. Therefore, a total of four mathematics lecturers were recruited for the study. During the first week, students responded to one instrument, i.e. the Differentiation Achievement Test as the pre-test, while treatment commenced in the second week and lasted for five weeks. The seventh week was used for the administration of the post-test DAT. In the experimental groups, students were assigned to mixed-ability teams of four or five members. Each chose a team name and was given the responsibility of ensuring that every team member learnt the content presented in their mathematics lessons. In each lesson, after initially explaining a target concept, on a whiteboard teachers posed a series of problems for students to solve in a "team huddle." They then called on a student at random from each team to represent the team with their answer and explanation. Because the students did not know which team mate would represent them, they had to ensure that all the members understood each problem and solution. The lecturers provided guidance and support during the team work activities, observed the team interaction and provided hints or clarifications and encouragement, bringing members into the discussion, acting in a pleasant and productive manner, and interceding when necessary in an encouraging way in order to ensure successful accomplishment of the task by the team. As the teams completed the problems, the results were exchanged among them for marking and to provide appropriate feedback to their peers. By this strategy, students not only deepened their understanding of the theory with the help of their classmates, but they also learned to talk together, to iron out issues, to evaluate and correct their mistakes, and to gain social skills. Finally, all the students were individually assessed, and teams were evaluated based on the average performance of all the team members. The control classes had their teaching and learning experience delivered under normal traditional arrangements throughout the five weeks. All the students who were exposed to co-operative learning and took the pre-test and post-test were classified as Experimental group I $\left(\mathrm{E}_{1}\right)$ or Cooperative Learning I $(\mathrm{n}=55)$; those who were taught with a conventional teaching approach and took the pre-test and post-test as Control group I $\left(\mathrm{C}_{1}\right)$ or Conventional Teaching I (n 
$=60$ ); and those who were exposed to co-operative learning and only took the post-test were classified as Experimental group II $\left(\mathrm{E}_{2}\right)$ or Cooperative Learning II $(\mathrm{n}=50)$. The students in Control group II $\left(\mathrm{C}_{2}\right)$ or Conventional Teaching II (n $=55)$ received a conventional teaching approach and only took the post-test.

The collected data were analysed using the descriptive statistics of mean and standard deviation, which served as precursors to adopting the inferential statistics of $4 \times 2$ Analysis of Variance (ANOVA), and the independent samples t-test. The two-way analysis of variance examined the influence of two different categorical independent variables (treatment and gender) on one continuous dependent variable (achievement in mathematics). It aimed to assess the main effect of each independent variable and also if there was any interaction between them (Gelman, 2005). ANOVA was employed to determine if the four groups differed significantly with regard to the experimental variable. An independent samples t-test was used to assess the differences in the pre-treatment (post-treatment) mean scores of the dependent measure between the experimental and control groups (with male and female participants) because of its superior quality in detecting differences between two groups (Awofala, 2016a).

\section{RESULTS}

In this part of the study, the results are presented based on the null hypotheses formulated. First, the assumption was that the two groups studied were homogenous. Consequently, the author sought this homogeneity in terms of their responses to the pre-treatment achievement test before the application of the treatment procedure (Awofala, 2016a; Wiersma \& Jurs, 2005). A pre-treatment achievement test was administered to the two groups, experimental group I $\left(\mathrm{E}_{1}\right)$ and control group $\mathrm{I}\left(\mathrm{C}_{1}\right)$. Table 3 shows that the mean for group $\mathrm{E}_{1}$ was 21.53 $(\mathrm{SD}=4.59)$, while that of group $\mathrm{C}_{1}$ was $21.50(\mathrm{SD}=4.40)$, meaning that of the former was slightly higher. Likewise, the standard deviation of group $\mathrm{E}_{1}$ was slightly higher than that of group $\mathrm{C}_{1}$. This means that the scores of group $\mathrm{E}_{1}$ spread away from the mean, while those of group $C_{1}$ were closer to the mean. Therefore, the level of achievement between groups $E_{1}$ and $C_{1}$ was not significantly different $[\mathrm{t}(113)=0.33, \mathrm{p}>.05]$, hence they showed similar features and were therefore found to be relevant for the study.

Table 3. Independent samples t-test results of the DAT pre-treatment scores of the pretreatment groups

\begin{tabular}{lllllll}
\hline Group & $\mathrm{N}$ & Mean & SD & Df & t-value & p-value \\
\hline $\mathrm{E}_{1}$ & 55 & 21.53 & 4.59 & 113 & 0.33 & 0.97 \\
\hline $\mathrm{C}_{1}$ & 60 & 21.50 & 4.40 & & & \\
\hline
\end{tabular}

The results in Table 4 show that the mean score for male students was 21.48 $(\mathrm{SD}=4.44)$, while that of their female counterparts was $21.52(\mathrm{SD}=4.34)$. The $\mathrm{t}-$ value was 0.06 , which showed that a statistically non-significant difference 
existed in mathematics achievement between male and female students. This nonsignificant difference in mean scores for both the pre-treatment groups and for gender necessitated the use of ANOVA to analyse the difference between the four groups in the post-treatment DAT scores.

Table 4. Independent samples t-test results of the pre-treatment DAT scores by gender

\begin{tabular}{lllllll}
\hline Gender & $\mathrm{N}$ & Mean & SD & Df & t-value & p-value \\
\hline Male & 108 & 21.48 & 4.44 & 218 & 0.06 & 0.95 \\
\hline Female & 112 & 21.52 & 4.34 & & & \\
\hline
\end{tabular}

Null Hypothesis One: There is no significant main effect of treatment on university students' achievement in mathematics

As shown in Table 5, the post-treatment DAT mean scores for the four groups were different. Groups $\mathrm{E}_{1}$ and $\mathrm{E}_{2}$ had mean scores of $32.82(\mathrm{SD}=3.82)$ and 32.60 $(\mathrm{SD}=3.94)$ respectively, while Groups $\mathrm{C}_{1}$ and $\mathrm{C}_{2}$ had mean scores of 24.63 $(\mathrm{SD}=5.59)$ and $23.22(\mathrm{SD}=5.12)$ respectively. It is a common knowledge to note that students in groups $\mathrm{E}_{1}($ mean $=32.82, \mathrm{SD}=3.82)$ and $\mathrm{E}_{2}($ mean=32.60, $\mathrm{SD}=3.94)$ had comparable mean scores, similarly students in groups $\mathrm{C}_{1}$ (mean=24.63, $\mathrm{SD}=5.59)$ and $\mathrm{C}_{2}($ mean=23.22, $\mathrm{SD}=5.12)$, but the students in groups $\mathrm{E}_{1}$ and $\mathrm{E}_{2}$ recorded higher mean scores than those in groups $\mathrm{C}_{1}$ and $\mathrm{C}_{2}$. This shows that the students in the experimental groups I and II taught mathematics with the cooperative learning strategy performed better than those in control groups I and II, who were taught with the conventional teaching method. Hence, the co-operative learning strategy was more effective than the conventional teaching method.

Table 5. Results of the statistical analysis of the post-treatment achievement scores based on treatment and gender

\begin{tabular}{lllll}
\hline Treatment & Gender & Mean & SD & N \\
& & & & \\
\hline Co-op. learning I $\left(\mathrm{E}_{1}\right)$ & Male & 32.32 & 4.19 & 28 \\
& Female & 33.33 & 3.39 & 27 \\
& Total & 32.82 & 3.82 & 55 \\
\hline Co-op. learning II $\left(\mathrm{E}_{2}\right)$ & Male & 32.92 & 3.59 & 24 \\
& Female & 32.31 & 4.30 & 26 \\
& Total & 32.60 & 3.94 & 50 \\
\hline Conv. teaching I $\left(\mathrm{C}_{1}\right)$ & Male & 25.00 & 6.45 & 32 \\
& Female & 24.24 & 4.57 & 29 \\
& Total & 24.63 & 5.59 & 60 \\
\hline Conv. teaching II $\left(\mathrm{C}_{2}\right)$ & Male & 23.80 & 4.62 & 25 \\
& Female & 22.73 & 5.53 & 30 \\
& Total & 23.22 & 5.12 & 55 \\
\hline Total & Male & 28.38 & 6.37 & 108 \\
& Female & 27.90 & 6.53 & 112 \\
& Total & 28.14 & 6.44 & 220 \\
\hline
\end{tabular}


Further analysis of the post-treatment achievement scores of the students in experimental groups I and II and control groups I and II using the analysis of covariance shown in Table 6 indicates that the difference in means between the four groups was statistically significant $\left(F_{(3,219)}=62.95, p=0.000, \eta^{2}{ }_{p}=0.471\right)$. The partial eta squares $\left(\eta^{2}\right)$, which is the proportion of the effect + error variance that is attributable to the effect (Awofala, Fatade \& Udeani, 2015) was only 0.498, which means that the factor treatment by itself accounted for only $47.1 \%$ of the overall (effect + error) variability in the university students' mathematics scores. This result suggests a large effect of treatment (Cohen, 1988). A significant result at a level of $\mathrm{p}<0.05$ means that there is a less than $5 \%$ chance that the result is simply due to randomness. The flip side of this was that there was a $95 \%$ chance that the difference in post-treatment achievement scores between the four groups was a real difference and not just due to chance. As observed in Table 6, the twotailed $\mathrm{p}$ value was 0.000 , which means that random sampling from identical populations would lead to a difference smaller than was observed in $100 \%$ of the experiments, and greater than was observed in $0 \%$ of the experiments. Therefore, null hypothesis 1 was rejected and it was concluded that there was a significant effect of treatment on university students' achievement in mathematics.

Table 6. Summary of the analysis of variance of achievement in mathematics scores by treatment and gender

\begin{tabular}{lllllll}
\hline Source & $\begin{array}{l}\text { Type III Sum } \\
\text { of Squares }\end{array}$ & MS & F & Sig & $\begin{array}{l}\text { Partial Eta } \\
\text { Squared }\end{array}$ \\
\hline Corr. model & $4311.253^{\mathrm{a}}$ & 7 & 615.893 & 27.404 .000 & .475 \\
Intercept & 1765358.642 & 1 & 175358.64 & $7.80 \mathrm{E} 3.000$ & .974 \\
treatment (T) & 4244.101 & 3 & 1414.700 & 62.946 .000 & .471 \\
Gender (G) & 6.906 & 1 & 6.906 & .307 & .580 & .001 \\
T×G & 35.834 & 3 & 11.945 & .531 & .661 & .007 \\
Error & 4764.656 & 212 & 22.475 & & & \\
Total & 183240.000 & 220 & & & & \\
Corr. Total & 9075.909 & 219 & & & & \\
\hline a. Squared & $.475(\mathrm{Adju}$ & & & &
\end{tabular}

a. R Squared $=.475$ (Adjusted R Squared $=.458$ )

After establishing that there was a significant difference between students in the four groups, it was appropriate to further confirm the direction of the difference. This was accomplished by post hoc tests of multiple comparisons using Tukey's honestly significanct difference (HSD) test (Montgomery, 2013). This test was deemed suitable for the study because a large number of groups were being compared and the test helps in reducing the likelihood of a Type I error occurring by identifying differences between groups. The results indicate that the differences in the mean scores of groups $E_{1}$ and $C_{1}$, groups $E_{1}$ and $C_{2}$, groups $E_{2}$ and $\mathrm{C}_{1}$ and groups $\mathrm{E}_{2}$ and $\mathrm{C}_{2}$ were statistically significant $(\mathrm{p}<.05)$, but that there was no statistically significant difference between groups $E_{1}$ and $E_{2}$ and groups $C_{1}$ and $\mathrm{C}_{2}$. 
Table 7. Result of multiple comparisons of the treatment level by Tukey's honestly significanct difference test

\begin{tabular}{|c|c|c|c|c|c|c|}
\hline \multirow[b]{2}{*}{ (I) Treatment } & \multirow[b]{2}{*}{ (J) Treatment } & \multirow{2}{*}{ Difference } & \multirow[b]{2}{*}{ Std. Error } & \multirow[b]{2}{*}{ Sig. } & \multicolumn{2}{|c|}{$\begin{array}{l}\text { 95\% Confidence } \\
\text { Interval }\end{array}$} \\
\hline & & & & & Lower Bound & Upper Bound \\
\hline \multirow[t]{3}{*}{$\begin{array}{l}\text { Cooperative } \\
\text { Learning I }\end{array}$} & $\begin{array}{l}\text { Cooperative } \\
\text { Learning II }\end{array}$ & .2182 & .92635 & .997 & -2.3924 & 2.8287 \\
\hline & $\begin{array}{l}\text { Conventional } \\
\text { Teaching I }\end{array}$ & $8.1848^{*}$ & .88499 & .000 & 5.6909 & 10.6788 \\
\hline & $\begin{array}{l}\text { Conventional } \\
\text { Teaching II }\end{array}$ & $9.6000^{*}$ & .90403 & .000 & 7.0524 & 12.1476 \\
\hline \multirow[t]{3}{*}{$\begin{array}{l}\text { Cooperative } \\
\text { Learning II }\end{array}$} & $\begin{array}{l}\text { Cooperative } \\
\text { Learning I }\end{array}$ & -.2182 & .92635 & .997 & -2.8287 & 2.3924 \\
\hline & $\begin{array}{l}\text { Conventional } \\
\text { Teaching I }\end{array}$ & $7.9667^{*}$ & .90779 & .000 & 5.4085 & 10.5249 \\
\hline & $\begin{array}{l}\text { Conventional } \\
\text { Teaching II }\end{array}$ & $9.3818^{*}$ & .92635 & .000 & 6.7713 & 11.9924 \\
\hline \multirow[t]{3}{*}{$\begin{array}{l}\text { Conventional } \\
\text { Teaching I }\end{array}$} & $\begin{array}{l}\text { Cooperative } \\
\text { Learning I }\end{array}$ & $-8.1848^{*}$ & .88499 & .000 & -10.6788 & -5.6909 \\
\hline & $\begin{array}{l}\text { Cooperative } \\
\text { Learning II }\end{array}$ & $-7.9667^{*}$ & .90779 & .000 & -10.5249 & -5.4085 \\
\hline & $\begin{array}{l}\text { Conventional } \\
\text { Teaching II }\end{array}$ & 1.4152 & .88499 & .467 & -1.0788 & 3.9091 \\
\hline \multirow[t]{3}{*}{$\begin{array}{l}\text { Conventional } \\
\text { Teaching II }\end{array}$} & $\begin{array}{l}\text { Cooperative } \\
\text { Learning I }\end{array}$ & $-9.6000^{*}$ & .90403 & .000 & -12.1476 & -7.0524 \\
\hline & $\begin{array}{l}\text { Cooperative } \\
\text { Learning II }\end{array}$ & $-9.3818^{*}$ & .92635 & .000 & -11.9924 & -6.7713 \\
\hline & $\begin{array}{l}\text { Conventional } \\
\text { Teaching I }\end{array}$ & -1.4152 & .88499 & .467 & -3.9091 & 1.0788 \\
\hline
\end{tabular}

Based on observed means.

The error term is Mean

Square(Error) $=22.475$.

*The mean difference is significant at the .05 level.

Null Hypothesis Two: There is no significant main effect of gender on university students' achievement in mathematics.

Table 5 shows that male students had a mean score of $28.38(\mathrm{SD}=6.37)$ in the post-test while the female students had a mean score of $27.90(\mathrm{SD}=6.53)$. This indicates that the male students performed slightly better. Therefore, there could still be slight gender difference in maths achievement in favour of male students. Further analysis of the post-treatment achievement scores of the male and female students using the Analysis of Variance shown in Table 7 indicates that the difference in means between the two groups was statistically not significant $\left(\mathrm{F}_{(1}\right.$, $\left.{ }_{219)}=0.31, \mathrm{p}=0.58, \eta_{\mathrm{p}}^{2}=0.001\right)$. Therefore, it was concluded that there was no significant effect of gender on students' achievement in mathematics.

Null Hypothesis Three: There is no significant interaction effect of treatment or gender on university students' achievement in mathematics. 
The results shown in Table 5 reveal that male students taught mathematics with the co-operative learning strategy in experimental group I had a mean score of 32.32 ( $\mathrm{SD}=4.19)$ in the post-test, while their female counterparts recorded a posttest mean score of 33.33 ( $\mathrm{SD}=3.39$ ). In experimental group II, taught with the cooperative learning strategy, male students had a mean score of $32.92(\mathrm{SD}=3.59)$ in the post-test, while their female counterparts recorded a post-test mean score of 32.31 ( $\mathrm{SD}=4.30)$. In addition, male students in control group I taught mathematics with the conventional teaching method had a mean score of $25.00(\mathrm{SD}=6.45)$ in the post-test, while their female counterparts recorded a post-test mean score of 24.24 ( $\mathrm{SD}=4.57)$. In control group II, taught with the conventional teaching method, male students had a mean score of 23.80 ( $\mathrm{SD}=4.62)$ in the post-test, while their female counterparts recorded a post-test mean score of 22.73 $(\mathrm{SD}=5.53)$. In light of these results, male and female students in both experimental groups I and II taught mathematics using the co-operative learning strategy gained comparably and maximally from the instruction than those taught in control groups I and II using the conventional teaching method.

Further analysis of the post-treatment achievement scores of the students based on treatment and gender, using the analysis of variance shown in Table 6, indicates that the interaction effect of treatment and gender was statistically not significant $\left(\mathrm{F}_{(3,219)}=0.53, \mathrm{p}=0.66, \eta_{\mathrm{p}}^{2}=0.007\right)$. Therefore, it was established that there was no significant interaction effect of treatment or gender on university students' achievement in mathematics.

\section{DISCUSSION}

The findings of this study have shown that the co-operative learning strategy enhanced learners' achievement in mathematics more than the conventional teaching method; Slavin and Lake (2008) previously claimed that there was a significant difference between the two approaches. The results show the more facilitative potential of the co-operative learning strategy in promoting achievement in mathematics over the conventional teaching method, thereby supporting the advocates of the former (Awofala, Fatade, \& Olaoluwa, 2012; Awofala, Arigbabu \& Awofala, 2013). The significant effect of the treatment is consistent with the findings of several studies on student-centred strategies, with co-operative learning being one of these (Lawal \& Awofala, 2019; Awofala, 2017a; Awofala, 2014; Awofala, 2011a; Awofala, 2011b; Awofala, Balogun \& Olagunju, 2011; Akinsola \& Awofala, 2008; Awofala, Fatade \& Ola-Oluwa, 2013; Awofala \& Nneji, 2011; Ojaleye \& Awofala, 2018). However, the significant evidence in favour of co-operative learning strategy is also inconsistent with some findings (e.g., Tracey, Madden, \& Slavin, 2010). The presence of a cooperative learning effect on achievement in mathematics in this study was probably a result of many factors.

Co-operative learning is particularly well-matched to mathematics, as it helps students to understand their own misconceptions in the process of engaging in the construction of meaning. Students in a group may all be learning material for the first time, and may be even more aware than their teacher of what other students 
do not understand. With appropriate guidance, they can give each other explanations that focus on their fellow students' misconceptions. Receiving such elaborated explanations can help students fill in gaps in their understanding, correct misconceptions, and strengthen connections between new information and previous learning (Webb, 2008). In essence, co-operative learning functions as a means of cognitive elaboration, helping students to both learn and understand (Webb, 2008; O’Donnell, 1996; Newbern, Dansereau, Patterson, \& Wallace, 1994). One other main reason why co-operative learning strategy is expected to enhance mathematics development is its ability to structure experiences that promote metacognition, defined as knowledge of one's own cognition. Therefore, co-operative learning allows the process of understanding why you know something and how you know it. This might have been the case of the students treated with the co-operative learning strategy in this study.

The non-significant difference confirmed in achievement in mathematics between male and female students in this study reveals that gender has no effect on students' achievement. This supports earlier findings (Awofala, 2017b; Fatade, Nneji, Awofala \& Awofala, 2012; Awofala \& Anyikwa, 2014), which have revealed no significant effect of gender on students' achievement in mathematics. However, the finding of this study on gender difference also contradict earlier studies (Awofala, 2011c; Awofala, 2008), which established a significant effect of gender on students' achievement in mathematics. The non-significant effect found in this study could be a result of the interaction pattern that prevailed in the classrooms, which did not favour one gender above the other (Awofala, 2016a). Eccles and Midgley (1989) maintain that students are highly motivated to learn when classroom situations are well adapted to their needs, interests, and skill levels. This might have been the portion of both male and female students in this study, because equal opportunities were given to them to learn mathematics. The results of this study indicate the non-existence of disparity in the experiences of males and females within and outside the classroom, and that gender differences in achievement in mathematics might be declining.

The non-significant interaction effect of treatment and gender documented in this study is in line with previous studies (Ojaleye \& Awofala, 2018; Ogunleye, Awofala \& Adekoya, 2014), which have shown that gender does not seem to interact with instruction to produce results. This means that the treatment conditions did not discriminate across gender in this study. Esiobu (2011) found that there was a significant difference in the academic achievement of boys and girls who were taught biology through the co-operative learning strategy, while Adeyemi (2008) recorded no significant difference in the achievement of boys and girls of comparable abilities when they were taught social studies through cooperative learning strategy. Similarly, Mahira and Azamat (2013) reported no significant gender difference in the mathematics achievement of students who were taught through the co-operative learning strategy. The results of this study imply that co-operative learning could be used to promote learning and narrow the gender gap in the learning of mathematics. Therefore, co-operative learning strategy could be used as a base for personalising instruction for both male and 
female students to enhance mathematics teaching effectiveness and creativity among mathematics students in Nigeria (Awofala, 2012; Awofala \& Fatade, 2015).

\section{CONCLUSION}

This study has investigated the effectiveness of applying co-operative learning strategy in a university-level mathematics course in terms of student achievement. Considering the co-operative interaction and team solutions, it is clear that cooperative learning helped to deepen students' understanding of the material, which in turn promoted higher achievement levels for the classes that undertook co-operative learning on the specific topic of differentiation. During the intervention, it was further observed that students were critical and seamlessly developed their logical thinking skills whilst working in a team. Less able students, who once would have become frustrated with individual work, exhibited low levels of strain and showed less stress and anxiety when solving mathematical problems in co-operation with fellow team members. Using this learning strategy at the university level in a subject that students always find difficult, and in a topic that students have always found challenging, has led to results that are significant and support the previous work on this ever-popular learning approach. Although the results of this study are positive and support the benefits of co-operative learning, one possible limitation is the relatively short period of co-operative learning. Therefore, one possible improvement would be to consider extending the duration and period of co-operative interaction. Based on the positive social effect of cooperative learning strategy on university students' achievement in mathematics in this study, it is paramount to adjust cooperative learning principles to enhance the needs of universities in Nigeria. Integrating technology to enhance the enactment of major pedagogical elements and to differentiate teaching and learning to improve the diverse needs of students may provide the opportunity to optimise mathematics results and attitudes (Awofala, 2016b) amongst Nigerian students.

\section{REFERENCES}

Adeyemi, B. A. (2008). Effects of cooperative learning and problem solving strategies on junior secondary school students' achievement in social studies. Journal of Educational Psychology, 16(3), 691-708.

Akinsola, M. K., \& Awofala, A. O. A. (2008). Effects of problem context and reasoning complexity on mathematics problem solving achievement and transfer of secondary school students. European Journal of Scientific Research, 20(3), 641-651.

Akinsola, M. K. \& Awofala, A. O. A. (2009). Effect of personalisation of instruction on students' achievement and self-efficacy in mathematics word problems. International Journal of Mathematical Education in Science and Technology, 40(3), 389-404. doi: 10.1080/00207390802643169. 
Ali, R., Hukamdad, Akhter, A., \& Khan, A. (2010). Effect of using problem solving method in teaching mathematics on the achievement of mathematics students. Asian Social Science, 6, 67-72.

Amit, M. \& Fried, M. N. (2002). Research, reform, and times of change. In: L.D. English (Ed.), Handbook of International Research in Mathematics Education. (pp. 355-381). Mahwah, NJ: Erlbaum.

Awofala, A. O. A. (2008). Women and the learning of mathematics. African Journal of Historical Sciences in Education, 3(1), 195-213.

Awofala, A. O. A. (2010). Impact of personalised instruction on senior secondary school learning outcomes in mathematics word problems. Unpublished PhD Thesis. University of Ibadan, Nigeria.

Awofala, A. O. A. (2011a). Effect of concept mapping strategy on students' achievement in junior secondary school mathematics. International Journal of Mathematics Trends \& Technology, 2(3), 11-16.

Awofala, A. O. A. (2011b). Effect of personalized, computer-based instruction on students' achievement in solving two-step word problems. International Journal of Mathematics Trends and Technology, 2(2), 5-10.

Awofala, A. O. A. (2011c). Is gender a factor in mathematics performance among Nigerian senior secondary school students with varying school organization and location? International Journal of Mathematics Trends and Technology, 2(3), 17-21.

Awofala, A. O. A. (2012). Development and factorial structure of students' evaluation of teaching effectiveness scale in mathematics. Cypriot Journal of Educational Sciences, 7(1), 33-44.

Awofala, A. O. A. (2014). Examining personalisation of instruction, attitudes toward and achievement in mathematics word problems among Nigerian senior secondary school students. International Journal of Education in Mathematics, Science and Technology, 2(4), 273-288.

Awofala, A. O. A. (2016a). Effect of personalisation of instruction on students' motivation to learn mathematics word problems in Nigeria. Turkish Journal of Computer and Mathematics Education, 7(3), 486-509.

Awofala, A. O. A. (2016b). Examining preservice mathematics teachers' attitudes toward mathematics. Nigerian Journal of Curriculum Studies, 23, 292300.

Awofala, A. O. A. (2017a). Effect of personalisation of instruction on students' anxiety in mathematical word problems in Nigeria, Bulgarian Journal of Science and Education Policy (BJSEP), 11(1), 83-120.

Awofala, A. O. A. (2017b). Assessing senior secondary school students' mathematical proficiency as related to gender and performance in mathematics in Nigeria. International Journal of Research in Education and Science, 3(2), 488-502.

Awofala, A. O. A. \& Anyikwa, B. E. (2014). Assessing adult learners' numeracy as related to gender and performance in arithmetic. New Approaches in Educational Research, 3(2), 83-92. doi:10.7821/near.3.2.83-92.

Awofala, A. O. A., Arigbabu, A. A. \& Awofala, A. A. (2013). Effects of framing and team assisted individualised instructional strategies on senior 
secondary school students' attitudes toward mathematics. Acta Didactica Napocensia, 6(1), 1 - 22.

Awofala, A. O. A., Balogun, T. A., \& Olagunju, M. A. (2011). Effects of three modes of personalisation on students' achievement in mathematics word problems in Nigeria. International Journal for Mathematics Teaching and Learning. $\quad$ Retrieved $24 \quad$ July 2019 from http://www.cimt.plymouth.ac.uk/journal/awofala.pdf.

Awofala, A. O. A., \& Fatade, A. O. (2015). Validation of the domains of creativity scale for Nigerian preservice science, technology, and mathematics teachers. Electronic Journal of Research in Educational Psychology, 13(1), 131-150. http://dx.doi.org/10.14204/ejrep.35.14057.

Awofala, A. O. A, Fatade, A. O. \& Ola-Oluwa, S. A. (2012). Achievement in cooperative and individualistic goal-structured junior secondary school mathematics classrooms in Nigeria International Journal of Mathematics Trends and Technology, 3(1), $7-12$.

Awofala, A. O. A., Fatade, A. O. \& Olaoluwa, S. A. (2013). Improving students' interest in solving mathematics word problems through personalisation of instruction. Indian Streams Research Journal, 3(1), 1-11.

Awofala, A. O. A., Fatade, A. O., \& Udeani, U. N. (2015). Nigerian preservice science, technology and mathematics teachers' computer self-efficacy: An exploration based on gender, age, and discipline of study. International Journal of Education in Mathematics, Science and Technology, 3(2), 101119.

Awofala, A. O. A. \& Nneji, L. M. (2011). Effects of framing and team assisted individualized instructional strategies on students' achievement in mathematics. Journal of the Science Teachers Association of Nigeria, 46(2), 60-71.

Burron, B., James, L., \& Ambrosio, A. (1993). The effects of cooperative learning in a physical science course for elementary/middle level preservice teachers. Journal of Research in Science Teaching, 30, 697707.

Celikten, O., Ipekcioglu, S., Ertepinar, H., \& Geban, O. (2012). The effect of the conceptual change oriented instruction through cooperative learning on 4th grade students' understanding of earth and sky concepts. Science Education International, 23(1), 84-96.

Cohen, J. (1988). Statistical power analysis for the behavioural sciences (2. Auflage). Hillsdale, NJ: Erlbaum.

Curtis, D. D. (2001). Exploring collaborative online learning. Journal of Asynchronous Learning Networks, 5, 21-34.

D'Souza, S. \& Wood, L. (2003). Tertiary students' views about group work in mathematics. In Proceedings of the Educational Research, Risks and Dilemmas-New Zealand Association for Research in Education (NZARE) and Australian Association for Research in Education (AARE) Joint Conference, The University of Auckland, Auckland, New Zealand, 29 November-3 December 2003; Available online: http://www.aare.edu.au/ 03pap/dso03154.pdf (accessed 7 June 2016). 
Davidson, N. (1985). Small group cooperative learning in mathematics: A selective view of the research. In R. Slavin (Ed.), Learning to Cooperate, Cooperating to Learn. (pp. 211-230). New York, NY: Plenum Press.

Ebrahim, A. (2012). The effect of cooperative learning strategies on elementary students' science achievement and social skills in Kuwait. International Journal of Science and Mathematics Education, 10(2), 293-314.

Eccles, J. S., \& Midgley, C. M. (1989). Stage-environment fit: Developmentally appropriate classrooms for young adolescents. In C. Ames \& R. Ames (Eds.), Research on Motivation in Education, vol. 3. (pp. 139-186). San Diego: Academic Press.

Education Alliance (2006). Closing the achievement gap: Best practices in teaching mathematics. The Education Alliance. Available online: www.educationalliance.org (accessed 22 April 2019).

Esiobu, G. O. (2011). Achieving gender equality in science class: Shift from competition to cooperative learning. Multicultural Educational and Technology Journal, 5(4), 244-257

Fatade, A. O., Nneji, L. M., Awofala, A. O. A., \& Awofala, A. A. (2012). Mode of entry and gender as determinants of Nigerian pre-service teachers' performance in degree mathematics and science courses, International Journal of Mathematics Trends and Technology, 3(3), 103-109.

Gall, M. D., Borg, W. R., \& Gall, J. P. (1996). Education research-an introduction (6th ed.). White Plains, N.Y: Longman.

Galton, M., Hargreaves, L., \& Pell, T. (2009). Group work and whole-class teaching with 11-to 14-year-olds compared. Cambridge Journal of Education, 39(1), 119-140.

Gelman, A. (2005). Analysis of variance? why it is more important than ever. The Annals of Statistics, 33(1), 1-53.

Gillies, R., \& Ashman, A. (1998). Behavior and interactions of children in cooperative groups in lower and middle elementary grades. Journal of Educational Psychology, 90, 1-12.

Hiebert, J., \& Wearne, D. (1993). Instructional tasks, classroom discourse, and student learning in second grade. American Educational Research Journal, 30, 393-425.

Johnson, D. W. \& Johnson, R. T. (2005). New developments in social interdependence theory. Psychological Monographs, 131(4), 285-358.

Johnson, D. W., \& Johnson, R. (1989). Cooperation and competition: Theory and research. Edina, MN: Interaction Book Company.

Johnson, D. W.\& Johnson, R. T. (1990). Social skills for successful group work. Educational Leadership, 47, 29-33.

Johnson, D. W., Johnson, R. \& Smith, K. A. (1998). Active learning: Cooperative in the college classroom (2nd edition). Edina, MN: Interaction Book Company.

Johnson, D. W., Johnson, R. T. \& Holubec, E. J. (1994). Cooperative learning in the classroom. VA: Association for Supervision and Curriculum Development.

Johnson, D. W., Johnson, R. T. \& Smith, K. A. (1991). Cooperative learning: Increasing college faculty instructional productivity. ASHE-ERIC Report 
on Higher Education; The George Washington University: Washington, DC, USA.

Johnson, D. W., Johnson, R. T. \& Smith, K. A. (2013). Cooperative learning: Improving university instruction by basing practice on validated theory. Journal on Excellence in University Teaching, 25, 85-118.

Kerr, N. \& Bruun, S. (1983). The dispensability of member effort and group motivation losses: Free-rider effects. J. Pers. Soc. Psychol., 44, 78-94.

Kilpatrick, J. (1992). A history of research in mathematics education. In: D.A Grouws (Ed.). Handbook of Research on Mathematics Teaching and Learning. (pp. 3-38). Macmillan: New York, NY.

Lararowtiz, R., Hertz-Lazaraowitz, R., \& Baird, J. (1994). Learning science in a cooperative setting: Academic achievement and affective outcomes. Journal of Research in Science Teaching, 31, 1121-1131.

Law, Y. (2011). The effects of cooperative learning on enhancing Hong Kong fifth graders' achievement goals, autonomous motivation and reading proficiency. Journal of Research in Reading, 34(4), 402-425.

Lawal, R. F. \& Awofala, A. O. A. (2019). Effect of lesson study on senior secondary school students' achievement in mathematics. Journal of Science, Technology, Mathematics and Education, 15(3), 49-65.

Lazarowitz, R., Baird, J., \& Bowlden, V. (1996). Teaching biology in a group mastery learning mode: High school student's academic achievement and affective outcomes. International Journal of Science Education, 18, 447462.

Lewin, K. (1948). Resolving social conflicts. New York: Harper.

Lonning, R. (1993). Effect of cooperative learning strategies on student verbal interaction and achievement during conceptual change instruction in 10th grade general science. Journal of Research in Science Teaching, 30, 10871101.

Marhira, H. \& Azamat, A. (2013). Traditional vs modern teaching methods. Advantages and disadvantages. $3^{\text {rd }}$ International Conference on Foreign Language Teaching and Applied Linguistics. Retrieved from http://eprint. ibu.edu.ba/1901/

Mathes, P., Fuchs, D., \& Fuchs, L. (1997). Cooperative story mapping. Remedial and Special Education, 18, 20-27.

McManus, S., \& Gettinger, M. (1996). Teacher and student evaluations of cooperative learning and observed interactive behaviors. The Journal of Educational Research, 90, 13-22.

Montgomery, D. C. (2013). Design and analysis of experiments (8th ed.).

Nardi, E. \& Stewart, S. (2003). Is mathematics T.I.R.E.D? A profile of quiet disaffection in the secondary mathematics classroom. British Educational Research Journal, 29, 345-367.

National Council of Teachers of Mathematics (1989). Curriculum and evaluation standards for school mathematics; National Council of Teachers of Mathematics: Reston, VA, USA.

National Council of Teachers of Mathematics (2011). Intervention: A position of the National Council of Teachers of Mathematics; National Council of Teachers of Mathematics: Reston, VA, USA. 
Newbern, D., Dansereau, D. F. Patterson, M. E., \& Wallace, D. S. (1994, April). Toward a science of cooperation. Paper presented at the annual meeting of the American Educational Research Association, New Orleans, LA.

O'Donnell, A. M. (2000). The effects of explicit incentives on scripted and unscripted cooperation. Journal of Educational Psychology, 88(1), 74-86.

Ogunleye, A., Awofala, A. O. A \& Adekoya, E. A. (2014). Effect of students' background knowledge of mathematics on senior secondary school students' achievement in physics. Chemistry: Bulgarian Journal of Science Education, 23(6), 863-880.

Ojaleye, O. \& Awofala, A. O. A. (2018). Blended learning and problem-based learning instructional strategies as determinants of senior secondary school students' achievement in algebra. International Journal of Research in Education and Science, 4(2), 486-501. DOI:10.21890/ijres. 428286.

Pierce, R. L., Cassady, J. C., Adams, C. M., Speirs Neumeister, K. L., Dixon, F. A., \& Cross, T. L. (2011). The effects of clustering and curriculum on the development of gifted learners' math achievement. Journal for the Education of the Gifted, 34(4), 569-594.

Shihusa, H. \& Keraro, F. N. (2009). Using advance organizers to enhance students' motivation in learning biology. Eurasia Journal of Mathematics, Science \& Technology Education, 5(4), 413-420.

Slavin, R. \& Lake, C. (2008). Effective programs in elementary mathematics; A best evidence synthesis. Review of Educational Research, 78(3), 427-515.

Smith, K.A. (1996). Cooperative learning: Making "group work" work. In: C. Bonwell, T. Sutherlund (Eds.). Active Learning: Lessons from Practice and Emerging Issues. New Directions for Teaching and Learning. (pp. 7182). San Francisco, CA: Jossey-Bass.

Souvignier, E., \& Kronenberger, J. (2007). Cooperative learning in third graders' jigsaw groups for mathematics and science with and without questioning training. British Journal of Educational Psychology, 77(4), 755-771. Retrieved from http://dx.doi.org/10.1348/000709906X173297

Stein, M. K., Grover, B. W., \& Henningsen, M. (1996). Building student capacity for mathematical thinking and reasoning: An analysis of mathematical tasks used in reform classrooms. American Educational Research Journal, 33(2), 455-488.

Tarim, K., (2009). The effects of cooperative learning on preschoolers' mathematics problem solving ability. Educational Studies in Mathematics, 72, 325-340. DOI: 10.1007/s10649-069-9197-x.

Tarmizi, R. A. \& Bayata, S. (2012). Collaborative problem-based learning in mathematics: A cognitive load perspective. Procedia- Social and Behavioral Sciences, 32, 344-350.

Tracey, L., Madden, N. A., \& Slavin, R. E. (2010). Effects of co-operative learning on the mathematics achievement of years 4 and 5 pupils in Britain: A randomised control trial. Effective Education, 2(1), 85-97.

Webb, N. M. (2008). Learning in small groups. In: T. L. Good (Ed.), 21st Century education: A reference handbook. Thousand Oaks, CA: Sage. 
Webb, N. M., Troper, J. D., \& Fall, R. (1995). Constructive activity and learning in collaborative small groups. Journal of Educational Psychology, 87, $406-423$.

Wiersma, W. \& Jurs, S. G. (2005). Research methods in education. An introduction. 8th edition. Boston: Pearson Publications.

Wood, T., Cobb, P., \& Yackel, E. (1991). Change in teaching mathematics: A Case Study. American Educational Research Journal, 28, 587-616. 
